\title{
EFFECT OF ARGON-ION IRRADIATION ON CAVITY FORMATION IN 18Cr10NiTi AUSTENITIC STEEL AND ITS STRENGTHENED VERSION
}

\author{
I.V. Kolodiy ${ }^{1}$, S.A. Karpov ${ }^{I}$, A.S. Kalchenko ${ }^{1}$, I.E. Kopanets ${ }^{1}$, M.A. Tikhonovsky ${ }^{1}$, \\ G.D. Tolstolutskaya ${ }^{1}$, A.N. Velikodnyi ${ }^{1}$, and V.N. Voyevodin ${ }^{1,2}$ \\ ${ }^{I}$ National Science Center “Kharkov Institute of Physics and Technology”, Kharkiv, Ukraine; \\ ${ }^{2}$ V.N. Karazin Kharkiv National University, Kharkiv, Ukraine \\ E-mail: kolodiy@kipt.kharkov.ua
}

The swelling behavior of $18 \mathrm{Cr} 10 \mathrm{NiTi}$ austenitic stainless steel and its strengthened by $\mathrm{Y}_{2} \mathrm{O}_{3}-\mathrm{ZrO}_{2}$ nanooxides version irradiated with 1.4 MeV Ar-ions up to dose 30 displacements per atom (dpa) with simultaneously implanted argon to the levels 200 appm at temperatures of $550 \ldots 650{ }^{\circ} \mathrm{C}$ was investigated. Transmission electron microscopy (TEM) has been used to study the resulting microstructure evolution. Cavities were observed in both materials. The overall swelling of ODS $18 \mathrm{Cr} 10 \mathrm{NiTi}$ steel reaches $0.1 \%$ which is about half as much as conventional $18 \mathrm{Cr} 10 \mathrm{NiTi}$ steel.

PACS: 52.40Hf, 28.52Fa, 68.49Sf, 79.20Rf

\section{INTRODUCTION}

Austenitic steels are used in nuclear power as material for pressure vessel internals and fuel claddings in fast reactors. In comparison with ferritic-martensitic steels they are characterized by higher high-temperature strength, but have lower radiation resistance [1]. An addition of nanosized oxide particles to these steels and the nanostructure state production that characterized by the presence of nanosized particles $(\sim 2 \ldots 10 \mathrm{~nm})$ with high density $\left(\sim 10^{15} \ldots 10^{16} \mathrm{~cm}^{-2}\right)$ and uniform distribution into the matrix are considered an effective way of improving their irradiation resistance. Moreover, the addition of the minor elements may offer the potential to improve the mechanical properties of ODS austenitic stainless steels. To predict radiation resistance of new steels it is necessary first to assess their resistance to radiation swelling. The ion irradiation experiments using light and heavy ions have been applied as surrogates for reactor irradiation with good success [2].

Irradiation causes two basic types of damage: on the one hand, atomic displacements resulting in vacancy and self-interstitial lattice defects, which subsequently cluster into loops and cavities; and on the other hand, nuclear reactions creating foreign elements, especially hydrogen and helium atoms, which precipitate into bubbles and grow by accumulation of vacancies.

It was shown [3] that argon can be used as an analogue of helium in implantation-and-annealing experiments, provided that the doses are adjusted so that the gas concentrations are equivalent. In addition, irradiation with heavier inert gases (in particular, Ar) leads to a greater transfer of energy during collisions and, therefore, to a higher dpa rate.

The objective of this work is to understand better the role of microstructure and composition of $18 \mathrm{Cr} 10 \mathrm{NiTi}$ steel at its mechanical alloying by $\mathrm{Y}_{2} \mathrm{O}_{3}-\mathrm{ZrO}_{2}$ nanooxides on the cavities formation and swelling after 1.4 $\mathrm{MeV} \mathrm{Ar}^{+}$irradiations in the temperature range of $550 \ldots 650^{\circ} \mathrm{C}$ to dose $\sim 30 \mathrm{dpa}$.

\section{MATERIAL AND METHODS}

In this study $18 \mathrm{Cr} 10 \mathrm{NiTi}$ austenitic stainless steel and its strengthened by $\mathrm{Y}_{2} \mathrm{O}_{3}-\mathrm{ZrO}_{2}$ nanooxides version were investigated. Commercial austenitic steel $18 \mathrm{Cr} 10 \mathrm{NiTi}$ was used as initial steel. ODS steel production included the mechanical alloying (MA) of steel powder with $0.5 \mathrm{wt}$ \% $\%$ of $\mathrm{Y}_{2} \mathrm{O}_{3}-\mathrm{ZrO}_{2}$ nanooxides with their subsequent compacting and mechanicalthermal treatment [4]. The chemical composition of the powder was determined experimentally (wt.\%): 65.51 Fe, 18.0 Cr, 10.76 Ni, 0.63 Ti, 1.63 Mn, and $0.41 \mathrm{Si}$. As a result, rolled ribbons of ODS $18 \mathrm{Cr} 10 \mathrm{NiTi}$ steel thickness of $200 \mu \mathrm{m}$ were obtained. The size of coherent-scattering domains (CSD) of the oxide nanopowders (determined by the XRD method) was $16.5 \mathrm{~nm}$, and the cubic lattice parameter was measured to be $1.0528 \mathrm{~nm}$. It is shown that steel powders after mechanical alloying contains both austenitic and ferritic phase approximately in equal parts for all compositions of the oxide nanopowder. Annealing at temperatures above $800^{\circ} \mathrm{C}$ leads to austenization, and, at the same time, increasing in CSD size and microstrains level decreasing. Austenitic matrix phase was observed in the ODS steel ribbons after the final thermal treatment.

Microstructural and swelling data were extracted using conventional techniques conducted on JEM100CX and JEM-2100 transmission electron microscopes, employing standard bright-field techniques. Analysis of TEM micrographs was performed using image processing software.

Samples of 18Cr10NiTi austenitic stainless steel and its ODS version for TEM studies were prepared as disks of $3 \mathrm{~mm}$ in diameter. Thin foils were obtained by mechanical thinning of the disks down to $130 \mu \mathrm{m}$ followed by electropolishing and short-term annealing. To remove a specified depth layer of material from irradiated side of the sample the electro-pulse technique was used [5].

The thickness of TEM samples were determined using a convergent beam electron diffraction (CBED) pattern acquired in the two-beam approximation [6]. The thickness estimation method is based on a comparison of the measured and simulated intensity profiles across the diffraction disc.

The initial pre-irradiation microstructures of $18 \mathrm{Cr} 10 \mathrm{NiTi}$ steel and its ODS version are shown in Fig. 1. The structure of $18 \mathrm{Cr} 10 \mathrm{NiTi}$ after solution annealing contains twins of annealing precipitates of 
second phase (carbides and titanium carbonitrides) and dislocations. Majority of perfect dislocation are extended on partial dislocation with stacking fault formation. Sum density of dislocation is $\sim 10^{8} \mathrm{~cm}^{-2}$. Average grain size was $\sim 30 \mu \mathrm{m}$ (see Fig. 1,a).

Grain structure of ODS steel (see Fig. 1,b) was the same approximately for all samples, average grain size was $1.2 \ldots 2.0 \mu \mathrm{m}$ (see Fig. 1,c). Significant concen-
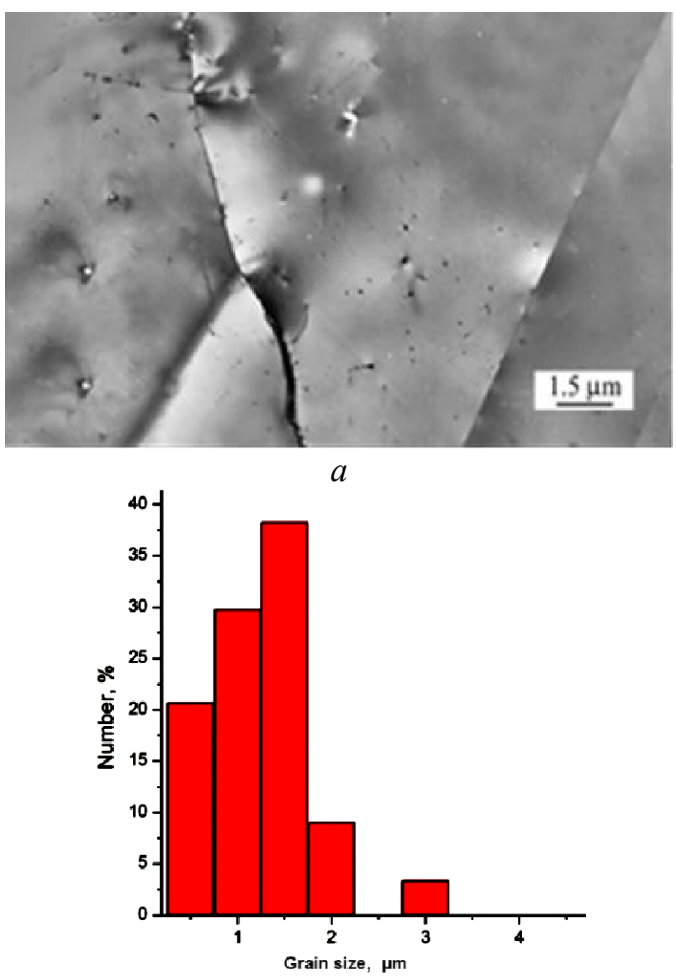

$c$ tration of precipitates and its near-uniform distribution are observed for all samples. Precipitations size varied from several nanometers to hundreds of nanometers, but the last were a few orders less, thus, its contribution to concentration and average size was negligible (see Fig. 1,d). Note, that calculations were performed on large data array (more than 1000 precipitates per composition).
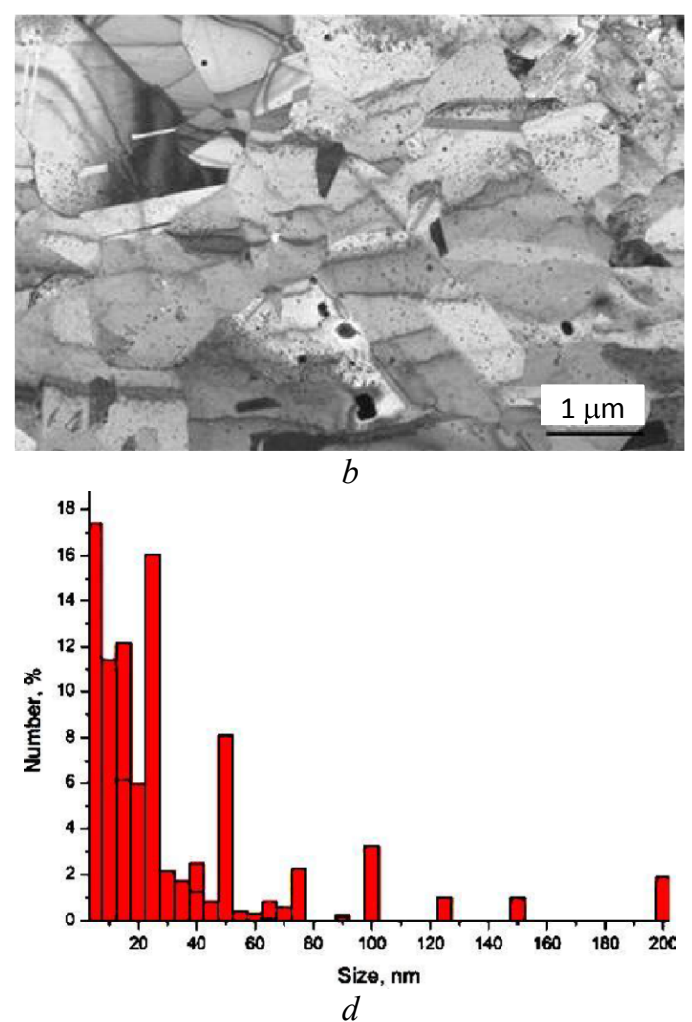

Fig. 1. Initial structure of $18 \mathrm{Cr} 10 \mathrm{NiTi}$ steel (a) and its ODS version (b); distribution of grain size (c) and size distribution of the oxide precipitates $(d)$ in ODS steel

The accelerating-measuring system "ESU-2" with an oil-free pumping system with a residual target-chamber pressure of $\sim 5 \cdot 10^{-5} \mathrm{~Pa}$ was used for the creation of radiation damage [7]. The argon ions with energy of 1.4 MeV were chosen for irradiation experiments. The irradiation temperature varied from 550 to $650{ }^{\circ} \mathrm{C}$. The error in the temperature measurement did not exceed $\pm 5 \%$. The error in the beam current and, consequently of the damage dose, did not exceed $\pm 10 \%$.

\section{RESULTS AND DISCUSSION}

Calculated by SRIM 2008 [8] depth distribution profiles of damage and concentration of $\mathrm{Ar}$ atoms implanted in $18 \mathrm{Cr} 10 \mathrm{NiTi}$ steel to a dose of $1 \cdot 10^{17} \mathrm{~cm}^{-2}$ are shown in Fig. 2. The damage calculations are based on the Kinchin-Pease model (KP), with a displacement energy for each alloying element was set to $40 \mathrm{eV}$, as recommended in ASTM E521-96 (2009) [9].

TEM observations have been performed on the first $100 \mathrm{~nm}$ from the surface where the incident ions of argon are virtually not deposited. Due to the dose gradient through the thin foil, an average value of $30 \mathrm{dpa}$ is considered. In average, the dpa rate is about $4 \cdot 10^{-3} \mathrm{dpa} / \mathrm{s}$.

TEM studies showed that irradiation with $1.4 \mathrm{MeV}$ argon ions is accompanied by the creation of cavity type defects. Fig. 3 shows TEM micrographs of the Arimplanted sample of $18 \mathrm{Cr} 10 \mathrm{NiTi}$ and ODS $18 \mathrm{Cr} 10 \mathrm{NiTi}$ steels to $30 \mathrm{dpa}$ at temperature $550 \ldots 650^{\circ} \mathrm{C}$.

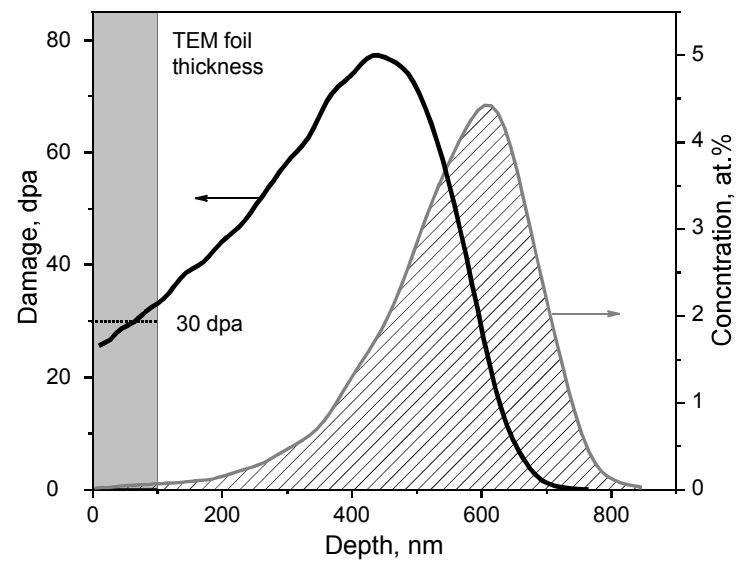

Fig. 2. The depth distribution of damage and concentration of Ar atoms calculated with SRIM for $18 \mathrm{Cr} 10 \mathrm{NiTi}$ irradiated $1.4 \mathrm{MeV}$ Ar ions to a dose of $1 \cdot 10^{17} \mathrm{~cm}^{-2}$

In the case of $18 \mathrm{Cr} 10 \mathrm{NiTi}$ irradiation with metallic ions (without gas co-injection) to the dose of $50 \mathrm{dpa}$ at a damage rate of $10^{-2} \mathrm{dpa} / \mathrm{s}$, the swelling was observed in the temperature range $590 \ldots 640^{\circ} \mathrm{C}$ [10]. At lower 
temperatures, high sink concentration and low effective vacancy diffusion coefficient reduce the vacancies supersaturation and, therefore, inhibit the formation and growth of voids [1]. However, the simultaneous

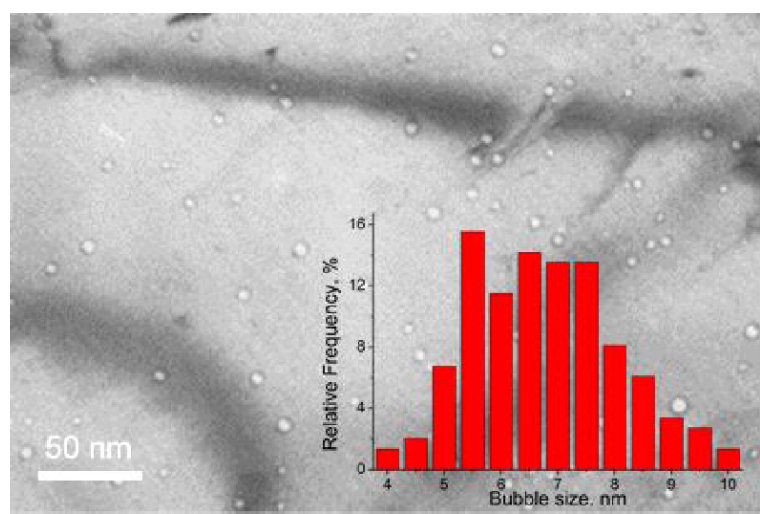

$a$

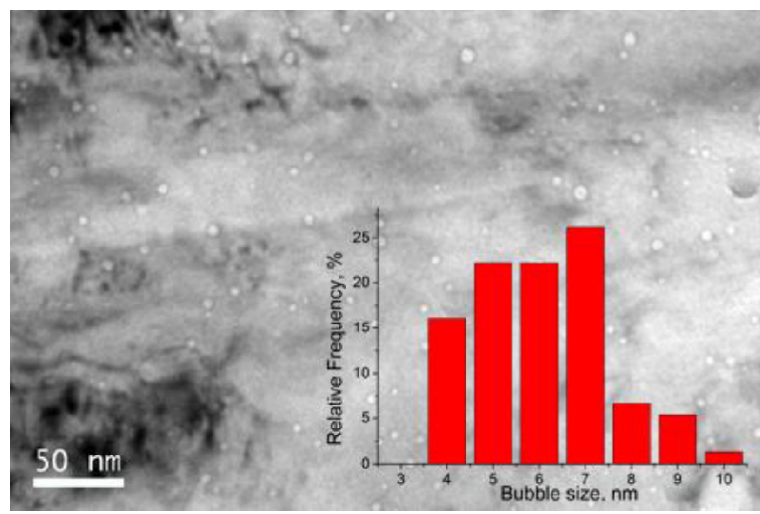

$c$

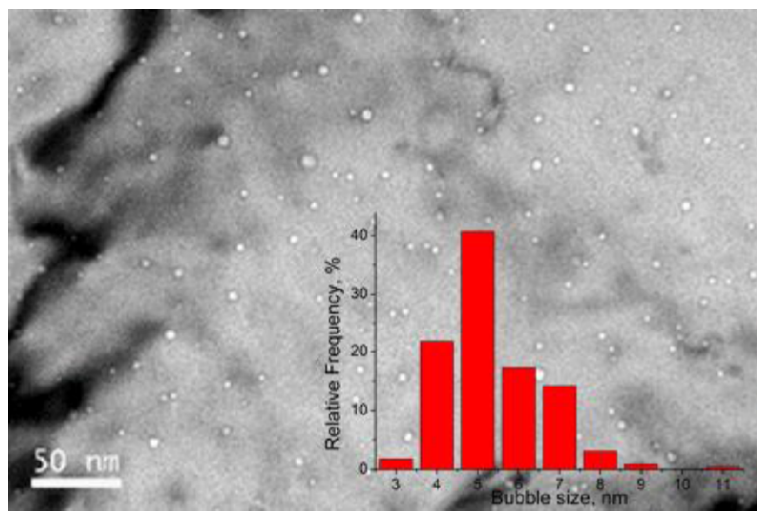

$e$

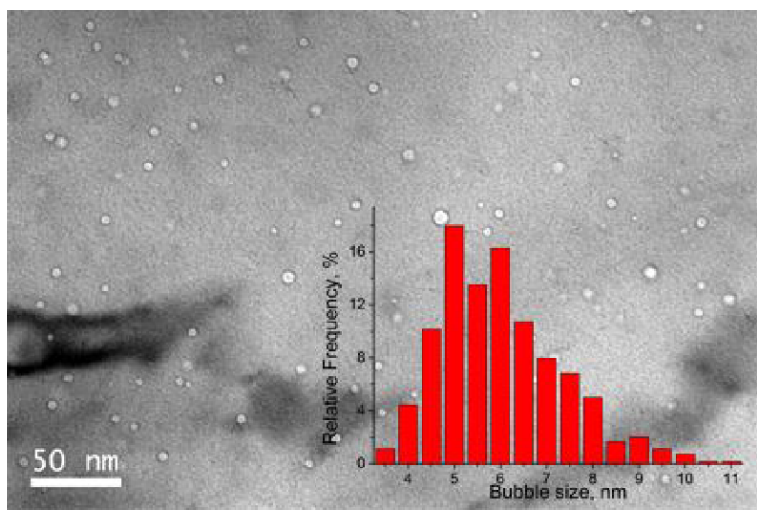

$g$ introduction of vacancies and argon (estimated concentration of argon atoms in the analyzed layer is about 200 appm) leads to the development of cavities even at $550^{\circ} \mathrm{C}$ (see Fig. 3).
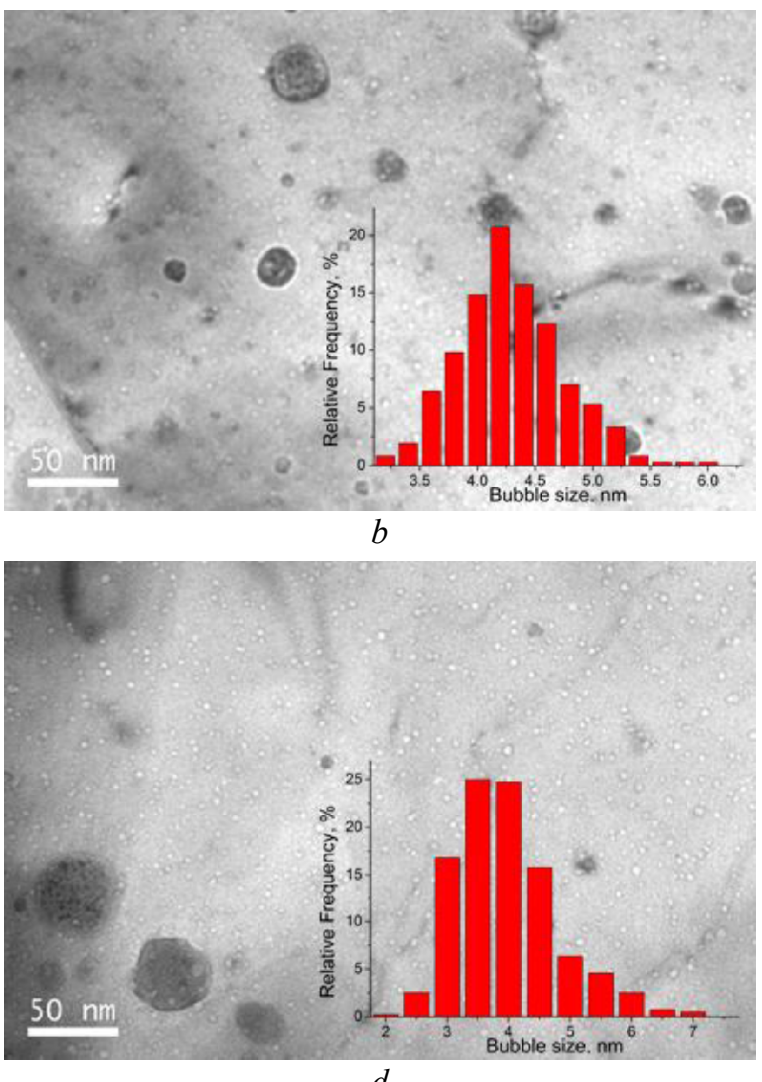

$d$

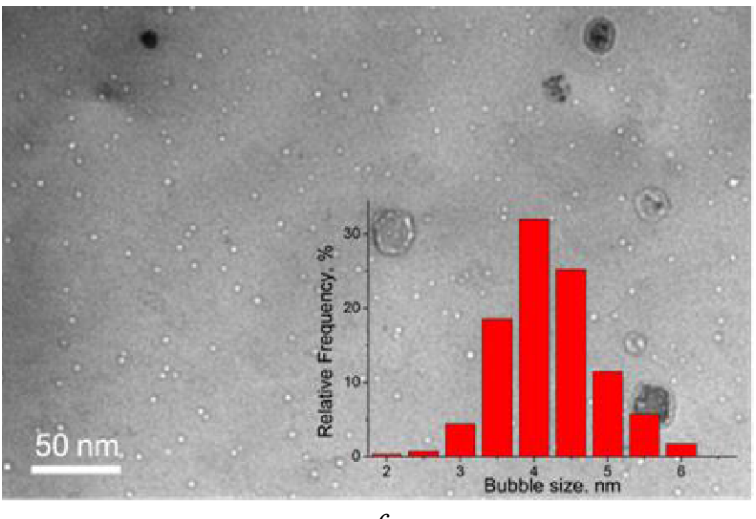

$f$

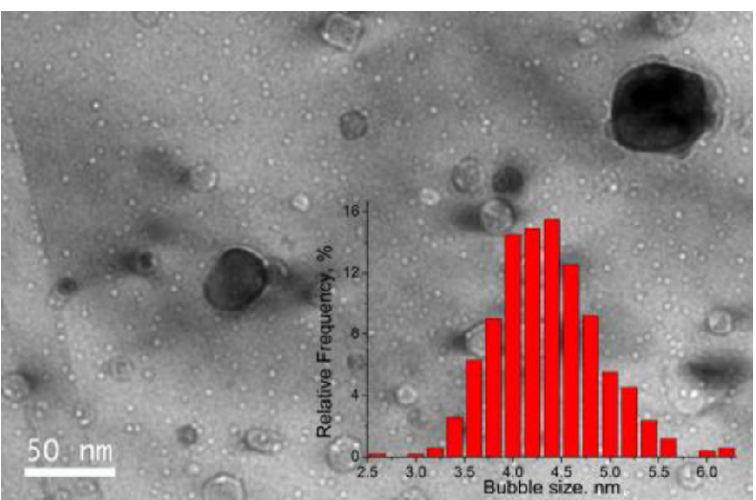

$h$

Fig. 3. TEM micrographs of the Ar-implanted sample of 18Cr10NiTi steel (a, c, e, g) and ODS 18Cr10NiTi steel $(b, d, f, h)$ to 30 dpa at temperature $550(a, b) ; 600(c, d) ; 625(e, f)$, and $650{ }^{\circ} \mathrm{C}(\mathrm{g}, \mathrm{h})$.

Cavity distributions in steel are shown in the inserts 
The cavities are characterized as bright regions surrounded by a darker band of contrast in Fig. 4. This classical Fresnel contrast arises when bubbles/voids are imaged in an under-focused condition, and reverses with an over-focused condition (see the insert in the Fig. 4).

Despite the fact that significant concentration of precipitates were distributed near-uniform over the sample, areas with reasonably inhomogeneous distribution of cavities throughout the matrix and from grain to grain are observed.

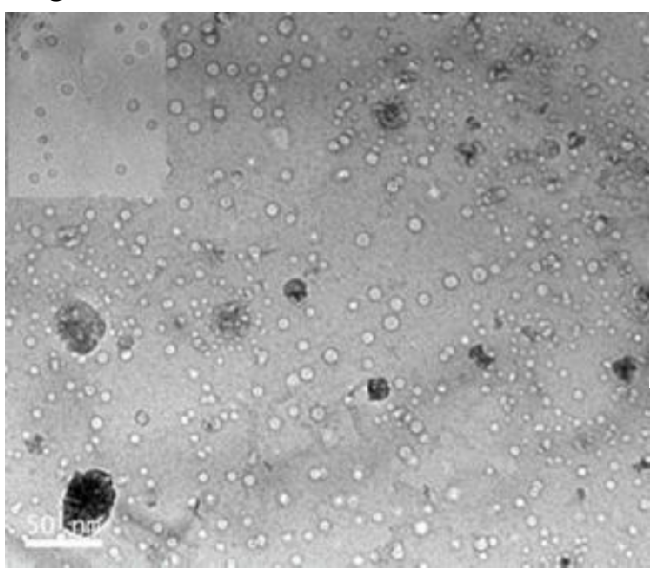

Fig. 4. Bright-field TEM micrograph of the ODS $18 \mathrm{Cr} 10 \mathrm{NiTi}$ steel irradiated at $625^{\circ} \mathrm{C}$ to $30 \mathrm{dpa}$

The local microstructure of the material plays a key role in the trapping of Ar particles and nucleation of cavities, and it is not unreasonable to assume that the microstructure between adjacent grains may be different due to the mechanical alloying process.

It is difficult to determine the exact composition of oxides. Fig. 5 and Table shows areas (indicated by crosshair or square) of EDS analysis and the corresponded chemical composition of the precipitate's particles $(\mathrm{Y}, \mathrm{Zr}, \mathrm{Ti})$ obtained by the EDS. Matrix elements were recorded as $21.7 ; 69$, and 9.8 at.\% for $\mathrm{Cr}$, $\mathrm{Fe}$, and $\mathrm{Ni}$, respectively. Oxygen is determined indicatively.

As can be seen from the table, the compositions of precipitates differ significantly, which confirms the conclusion that they correspond to the different (Y, Ti, Zr)-O compounds $[11,12]$.

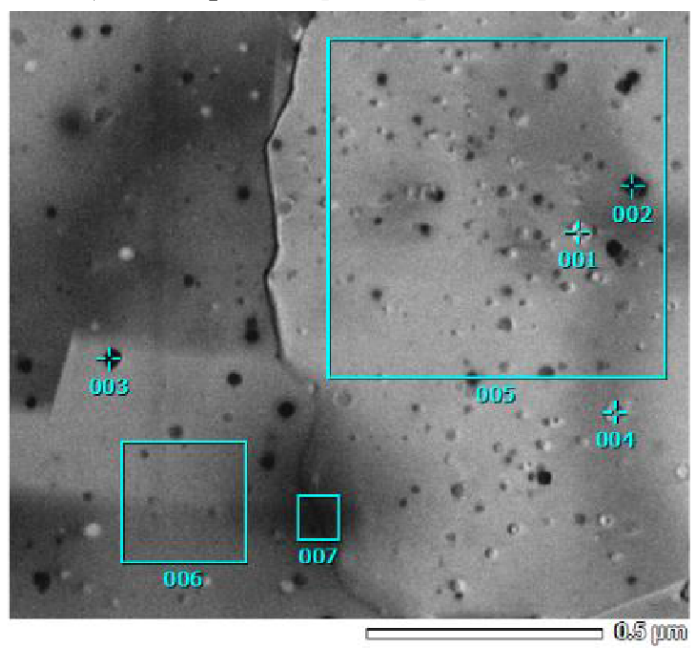

Fig. 5. Bright-field TEM micrograph of the ODS $18 \mathrm{Cr} 10 \mathrm{NiTi}$ steel with marked areas of EDS analyze
Coarse precipitates composition (at.\%)

\begin{tabular}{|c|c|c|c|c|c|}
\hline $\begin{array}{c}\text { \# probe/ } \\
\text { element }\end{array}$ & 001 & 002 & 003 & 004 & 005 \\
\hline $\mathrm{Y}$ & 20.49 & 11.85 & 9.05 & 18.77 & 0.6 \\
\hline $\mathrm{Zr}$ & 11.82 & - & 5.15 & 11.52 & 0.23 \\
\hline $\mathrm{Ti}$ & 2.06 & 1.32 & 3.50 & 2.11 & 0.41 \\
\hline
\end{tabular}

As can be seen from Fig. 4, the cavities are grouped near the precipitates. The cavities started to nucleate and grew at the interface between some oxide particles and matrix. This result indicates that the oxide/matrix interface acts as a sink for vacancies. High concentration of vacancies contributes to the nucleation of cavities at the interface, which is consistent to previous observations in ODS ferritic/martensitic steels [13] and ODS austenitic steels [14]. Not only at the particle/matrix interfaces, but as shown in Fig. 3, segregation of cavities at grain boundaries and twin boundaries were also observed.

Argon atoms can also contribute to the nucleation of cavities at the oxide/matrix interface. Argon can trap vacancies and stabilize them, to enhance the cavity nucleation $[15,16]$. In this case, cavities formed around the precipitates have a density increased by several times and an average diameter in 2-3 times smaller than the cavities formed far from the precipitates.

The mean size and density of cavities in ODS $18 \mathrm{Cr} 10 \mathrm{NiTi}$ steel were smaller and higher, respectively, as compared to those in conventional $18 \mathrm{Cr} 10 \mathrm{NiTi}$ steel (see Fig. 3). This indicates that the fine dispersed oxide particles are effective in suppression of cavity coarsening and contributes to limiting defect clusters to small size. Fig. 6 shows the temperature dependence of the swelling of $18 \mathrm{Cr} 10 \mathrm{NiTi}$ austenitic stainless steel and its ODS version.

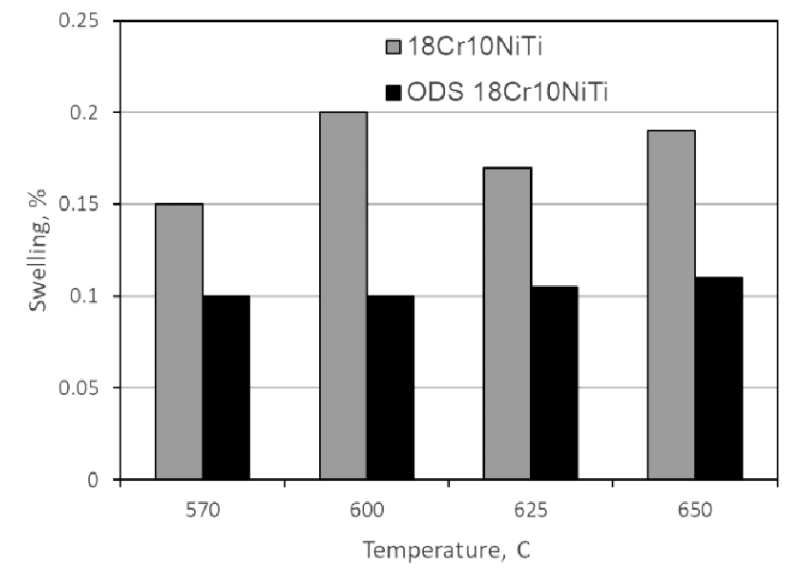

Fig. 6. Evolution with temperature of the swelling for 18Cr10NiTi (gray) and ODS 18Cr10NiTi (black) steels

As can be seen from Fig. 6, after irradiation of $18 \mathrm{Cr} 10 \mathrm{NiTi}$ steel and its ODS version with high-energy argon ions the swelling has a low value and weakly depends on the irradiation temperature, especially in the case of ODS steel. The swelling value is $0.15 \ldots 0.2 \%$ for $18 \mathrm{Cr} 10 \mathrm{NiTi}$ and $\sim 0.1 \%$ for ODS $18 \mathrm{Cr} 10 \mathrm{NiTi}$ steels.

Analysis of the literature data has showed that recently, there has been an insignificant swelling at examination of specimens generated from past irradiation programs. After irradiation in the EBR-II reactor at low dose rates $\left(\sim 2 \cdot 10^{-8} \mathrm{dpa} / \mathrm{s}\right)$ to $24.15 \mathrm{dpa}$ at 
$\sim 371 \ldots 389^{\circ} \mathrm{C}, \quad$ a $\quad$ series of microstructural modifications in SS304 and X-750 nickel base alloy were identified. It was shown that even though cavities are commonly found in both SS304 and X-750, the overall swelling of both alloys is minimal $(0.11 \%$ in SS304 and $0.0044 \%$ in X-750) [17]. An estimation of the helium content in SS304 and X-750 indicate the cavities in SS304 are voids, whereas the cavities in $\mathrm{X}-750$ could be helium bubbles.

ODS steels exhibit a lower level of swelling than equivalent steels without ODS dispersoids [18, 19]. Suggested reasons for the radiation resistance exhibited by precipitate-matrix interface sinks and ODS steels have been summarized in [19-21]. One idea is that the oxides provide a catalyst for annihilation of the structural defects (vacancies and SIAs caused by radiation). This could be either due to some attraction between the oxide and the defects, or altered defect dynamics at the interface boundary combined with the high density of particles. Another idea is that the disorder already brought about by the oxide dispersions in the steel structure make further disruptions caused by radiation less effective in weakening the material. A third is based on the original purpose of ODS: that the increased density of pinned dislocations promotes recombination.

Anyway, in some cases the microstructure at $\sim 100$ dpa does not seem to correspond to the domain of significant swelling by noticeable cavity growth. It appears that the linear swelling domain with $1 \% / \mathrm{dpa}$ rate [22] is not reached. In Ref. [23], it is indeed suggested that at "lower" PWR-relevant temperatures, a bounding estimate for the swelling rate might be $\sim 0.07 \%$ /dpa. In work [24], the swelling rate between intermediate and high dose is only $\sim 0.003 \% / \mathrm{dpa}$, still lower than this bounding estimate.

\section{CONCLUSION}

This paper shows the changes in microstructure and swelling of austenitic $18 \mathrm{Cr} 10 \mathrm{NiTi}$ and its ODS version after $1.4 \mathrm{MeV} \mathrm{Ar}{ }^{+}$irradiations in the temperature range of $550 \ldots 650{ }^{\circ} \mathrm{C}$ to dose $30 \mathrm{dpa}$ with simultaneously implanted argon levels of 200 appm at nominal Ar/dpa ratios of $7 \mathrm{appm} / \mathrm{dpa}$ and provides the following conclusions:

Irradiation is accompanied by the creation of cavity type defects. Complex Y-Ti-Zr-O nanoparticles, grain boundaries, and twin boundaries act as strong traps for cavities.

Cavities formed around the precipitates have a density increased by several times and an average diameter in 2-3 times smaller than the cavities formed far from the precipitates. It is might mean that adding oxide nanoparticles can improve the radiation resistance.

Argon shifts the temperature of the onset of swelling to the region of low temperatures.

The overall swelling of the ODS $18 \mathrm{Cr} 10 \mathrm{NiTi}$ steel is minimal after $1.4 \mathrm{MeV} \mathrm{Ar}^{+}$irradiations in the temperature range of $550 \ldots 650{ }^{\circ} \mathrm{C}$ to dose $30 \mathrm{dpa}$ and reaches $0.1 \%$ which is about half as much as conventional $18 \mathrm{Cr} 10 \mathrm{NiTi}$ steel.

\section{REFERENCES}

1. V.N. Voyevodin and I.M. Neklyudov. Evolution of the Structural-Phase State and Radiation Resistance of Structural Materials. Kiev: "Naukova Dumka", 2006.

2. P. Yvon and F. Carre. Structural materials challenges for advanced reactor systems // J. Nucl. Mater. 2009, v. 385, p. 217-222.

3. G.D. Tolstolutskaya, S.A. Karpov, A.S. Kalchenko, I.E. Kopanets, A.V. Nikitin, and V.N. Voyevodin. Effect of argon-ion irradiation on cavity ormation and evolution in $18 \mathrm{Cr} 10 \mathrm{NiTi}$ austenitic steel // Problems of Atomic Science and Technology. Series "Physics of Radiation Effect and Radiation Materials Science". 2020, N 2(126), p. 27-32.

4. A.N. Velikodnyi, V.N. Voyevodin, M.A. Tikhonovsky, V.V. Bryk, A.S. Kalchenko, S.V. Starostenko, I.V. Kolodiy, V.S. Okovit, A.M. Bovda, L.V. Onischenko, and G.Ye. Storogilov. Structure and properties of austenitic ODS steel 08Cr18Ni10Ti // Problems of Atomic Science and Technology. 2014, N 4(92), p. 94-102.

5. M.B. Toloczko, F.A. Garner, V.N. Voyevodin, et al. Ion-induced swelling of ODS ferritic alloy MA957 tubing to $500 \mathrm{dpa} / / \mathrm{J}$. Nucl. Mater. 2014, v. 453, p. 323-333.

6. M. Klinger. More features, more tools, more CrysTBox // Journal of Applied Crystallography. 2017, v. 50, p. 1-9.

7. G.D. Tolstolutskaya, V.V. Ruzhytskiy, I.E. Kopanetz, V.N. Voyevodin, A.V. Nikitin, S.A. Karpov, A.A. Makienko, T.M. Slusarenko. Accelerating complex for study of helium and hydrogen behavior in conditions of radiation defects generation // Problems of Atomic Science and Technology. Series "Physics of Radiation Effect and Radiation Materials Science". 2010, N 1, p. 135-140.

8. http://www.srim.org/

9. ASTM E521-96, 2009, ASTM.

10. O.V. Borodin, V.V. Bryk, A.S. Kalchenko, et al. Synergistic effects of helium and hydrogen on self-ioninduced swelling of austenitic 18Cr10NiTi stainless steel // J. Nucl. Mater. 2013, v. 442, p. S817-S820.

11. S.V. Starostenko, V.M. Voyevodin, M.A. Tykhonovs'kyi, et al. Microstructure of $08 \mathrm{Kh} 18 \mathrm{Ni10Ti}$ austenitic steel mechanically alloyed with nanooxides of the $\mathrm{Y}_{2} \mathrm{O}_{3}-\mathrm{ZrO} 2$ system // Materials Science. 2016, v. 51, N 6, p. 827-832.

12. С.В. Старостенко, В.Н. Воеводин, А.С. Кальченко, А.Н. Великодный, М.А. Тихоновский. Влияние облучения тяжелыми ионами $\mathrm{Cr}^{3+}$ на микроструктуру стали 08X18Н10T ДУО, механически легированной нанопорошком системы $\mathrm{Y}_{2} \mathrm{O}_{3}-\mathrm{ZrO}_{2} / /$ ВАНТ. Серия «Физика радиачионных повреждений и радиачионное материаловедение». 2016, №4(104), c. 3-8.

13. K. Yutani, H. Kishimoto, R. Kasada, A. Kimura. Evaluation of Helium effects on swelling behavior of oxide dispersion strengthened ferritic steels under ion irradiation // J. Nucl. Mater. 2007, v. 367-370, part A, p. 423-427.

14. H. Oka, M. Watanabe, H. Kinoshita, T. Shibayama, N. Hashimoto, S. Ohnuki, S. Yamashita, 
S. Ohtsuka. In situ observation of damage structure in ODS austenitic steel during electron irradiation // $J$. Nucl. Mater. 2011, v. 417, issues 1-3, p. 279-282.

15. D.J. Mazey, B.C. Sowden, E.J. Jones. Mixed $\mathrm{Ne} / \mathrm{Ni}$ beams for radiation damage studies on the Harwell variable energy cyclotron // Nuclear Instruments and Methods in Physics Research. 1985, v. B12, p. $419-425 \mathrm{~N}$.

16. N. Marochov and P.J. Goodhew. A comparison of the growth of helium and neon bubbles in nickel // J. Nucl. Mater. 1988, v. 158, p. 81-86.

17. X. Liu, L. He, H. Yan, M. Bachhav, J.F. Stubbins. A transmission electron microscopy study of EBRII neutron-irradiated austenitic stainless steel 304 and nickel-base alloy X-750 // J. Nucl. Mater. 2020, v. 528, p. 151851

18. R. Lindau, A. Möslang, M. Schirra, P. Schlossmacher, M. Klimenkov. Mechanical and microstructural properties of a hipped RAFM ODS-steel // $J$. Nucl. Mater. 2002, v. 307-311, p. 769-772.

19. R. Schäublin, A. Ramar, N. Baluc, et al. Microstructural development under irradiation in European ODS ferritic/martensitic steels // J. Nucl. Mater. 2006, v. 158351, p. 247-260.

20. A.D. Brailsford, L.K. Mansur. The effect of precipitate-matrix interface sinks on the growth of voids in the matrix // J. Nucl. Mater. 1981, v. 104, p. 14031408 .

21. J. Brodrick, D.J. Hepburn, G.J. Ackland. Mechanism for radiation damage resistance in yttrium oxide dispersion strengthened steels // J. Nucl. Mater. 2014, v. 445, p. 291-297.

22. F. Garner, A. Kumar. The influence of both major and minor element composition on void swelling in austenitic steels // Radiation-Induced Changes in Microstructure: 13th International Symposium (Part I), v. 955, ASTM STP, 1987, p. 289-314.

23. F.A. Garner. New data and insights on prediction of void swelling in austenitic pressure vessel internals // Proceedings Fontevraud 9 - Contribution of Materials Investigations and Operating Experience to Light Water NPPs' Safety, Performance and Reliability, September 2018, Avignon.

24. J. Malaplate, B. Michaut, A. Renault-Laborne, T. Jourdan, F. Dalle, J. Ribis, B. Radiguet, F. Sefta, B. Decamps. Characterization of ion irradiated microstructure and cavity swelling evolution up to high doses in austenitic stainless steels representative of PWR internals // J. Nucl. Mater. 2019, v. 517, p. 201213.

Article received 30.06.2020

\section{ВЛИЯНИЕ ОБЛУЧЕНИЯ ИОНАМИ АРГОНА НА ОБРАЗОВАНИЕ ПОРИСТОСТИ В АУСТЕНИТНОЙ СТАЛИ Х18Н10Т И ЕЕ УПРОЧНЕННОЙ ВЕРСИИ \\ И.В. Колодий, С.А. Карпов, А.С. Кальченко, И.Е. Копанец, М.А. Тихоновский, Г.Д. Толстолуцкая, А.Н. Великодный и В.Н. Воеводин}

Исследовано распухание аустенитной нержавеющей стали Х18Н10Т и ее дисперсно-упрочненной нанооксидами системы $\mathrm{Y}_{2} \mathrm{O}_{3}-\mathrm{ZrO}_{2}$-версии, облученных энергетичными ионами $\mathrm{Ar}$ с энергией 1,4 МэВ до дозы 30 смещений на атом (сна) с одновременно имплантированными атомами аргона до 200 appm в диапазоне температур $550 \ldots 650^{\circ} \mathrm{C}$. Для изучения эволюции микроструктуры была использована просвечивающая электронная микроскопия (ПЭМ). Полости наблюдались в обоих материалах. Общее распухание ДУО Х18Н10Т стали достигает $0,1 \%$, что примерно вдвое меньше, чем в обычной стали $\mathrm{X} 18 \mathrm{H} 10 \mathrm{~T}$.

\section{ВПЛИВ ОПРОМІНЕННЯ ІОНАМИ АРГОНУ НА УТВОРЕННЯ ПОРИСТОСТІ В АУСТЕНІТНОЇ СТАЛІ Х18Н10Т ТА ЇЇ ЗМЩНЕНОЇ ВЕРСІЇ}

\section{І.В. Колодій, С.О. Карпов, О.С. Кальченко, І.С. Копанець, М.А. Тихоновський, Г.Д. Толстолуцька, О.М. Великодний і В.М. Воєводін}

Досліджено розпухання аустенітної нержавіючої сталі X18Н10T і ї̈ дисперсно-зміцненої нанооксидами системи $\mathrm{Y}_{2} \mathrm{O}_{3}-\mathrm{ZrO}_{2}$-версії, опромінених енергетичними іонами $\mathrm{Ar}$ з енергією 1,4 MеВ до дози 30 зміщінь на атом (зна) з одночасно імплантованими атомами аргону до $200 \mathrm{appm}$ у діапазоні температур $550 \ldots 650{ }^{\circ} \mathrm{C}$. Для вивчення еволюції мікроструктури була використана просвічуюча електронна мікроскопія (ПЕМ). Порожнини спостерігалися в обох матеріалах. Загальне розпухання ДЗО Х18Н10Т сталі досягає $0,1 \%$, що приблизно вдвічі менше, ніж для звичайної стали Х18Н10Т. 